Agro Ekonomi Vol. 27/No. 1, Juni 2016

\title{
DEVELOPMENT STRATEGIC FARMING SYSTEM OF LOCAL COFFEE IN KEPULAUAN YAPEN REGENCY-PROVINCE OF PAPUA
}

\author{
Strategi Pengembangan Usahatani Kopi Lokal Di Kabupaten Kepulauan Yapen \\ - Propinsi Papua
}

\author{
Elias Edison Kapitarau1, Slamet Hartono ${ }^{2}$, Irham² \\ 1Dinas Perkebunan Kabupaten Kepulauan Yapen, Provinsi Papua \\ Jl. Flora, Bulaksumur, Yogyakarta 55281 \\ ${ }^{2}$ Dinas Perkebunan Kabupaten Kepulauan Yapen,Provinsi Papua \\ Jl. Sudirman, Famboaman, Yapen Selatan., Kabupaten Kepulauan Yapen, Papua 98213 \\ eliasedisonkapitarau@gmail.com
}

Diterima tanggal : 22 Januari 2016 ; Disetujui tanggal : 17 April 2016

\begin{abstract}
This research conducted in Kepulauan Yapen Regency Province of Papua. Objectives of this research to: (1) knowing and explaining internal factors (weakness and strength) and factors of external (threat and opportunity) farming system of local coffee Kepulauan Yapen Regency Province of Papua, (2) Formulating for development strategy of farming system local coffee correct to be applied in KepulauanYapen Regency Province of Papua. Method used in this study is descriptive analysis method. Determine of location done by purposive. Data part of primary and secondary data. Samples of respondent counted 40 and for Analysis of data using SWOT method. Result of SWOT analysis and IFAS-EFAS matrix show development of farming system district Kepulauan Yapen Province of Papua reside in II quadrant with weakness factor and opportunity more uppermost than threat and strength. Weakness more uppermost at that is exploiting of land in farming system of local coffee, plantation local coffee which have is old, not plant superioring seed of local of coffee, widespread land of farming location and the limited officer of extension agent (PPL). While opportunities which must be exploited wide of farming area, land is fertile and climate supporting growth coffee crop. Using superioring seed will be able to increase product and productivity local coffee. Formulation of the core strategies that should be used as a local coffee farm development strategy in Kepulauan YapenRegency namely; optimizing land, improving farming techniques, to establish areas of local development of coffee farming an affordable, performing a selection of local coffee varieties and build the garden collection, increase farmers'land ownership status are certified, Pursue partnerships and improve human resources/farmers local coffee in KepulauanYapen Regency.
\end{abstract}

Keywords: Development, LocalCcoffee, Strategy,

\section{INTISARI}

Penelitian ini dilaksanakan di Kabupaten Kepulauan Yapen Propinsi Papua. Tujuan penelitian ini untuk: (1) Mengetahui dan menjelaskan faktor-faktor internal (kekuatan dan kelemahan) dan faktor-faktor eksternal (peluang dan ancaman) usahatani kopi lokal di Kabupaten kepulauan Yapen, (2) memformulasikan strategi pengembangan usahatani kopi lokal yang tepat untuk diterapkan di Kabupaten Kepulauan Yapen. Metode yang digunakan adalah 
metode analisis deskriptif. Penentuan lokasi dilakukan secara purposive. Data yang digunakan adalah data primer dan data sekunder. Sampel yang diambil sebanyak 40 responden. Data dianalisis menggunakan metode analisis SWOT. Hasil analisis SWOT dan matrik IFASEFAS menunjukkan pengembangan usahatani kopi lokal di Kabupaten Kepulauan Yapen berada pada kuadran II dengan faktor kelemahan dan peluang lebih menonjol daripada kekuatan dan ancaman. Kelemahan lebih menonjol pada belum optimalnya pemanfaatan lahan usahatani,sebagian besartanaman kopi lokal telah tua,lokasi /kebun kopi yang letaknya terpencar-pencar, tidak ditanamnya bibit unggul kopi lokal, Rendahnya teknik budidaya kopilokal yang baik, terbatasnya petugas penyuluh lapangan danterbatasnya informasi dan teknologi pertanian. Sedangkan peluang yang harus dimanfaatkan adalah lahan potensial yang luas dan iklim yang mendukung pertumbuhan tanaman kopi,permintaan kopi lokal dalam negeri terbuka lebar dan adanya otonomi daerah. Formulasi strategi inti (core strategy) yang dapat dijadikan strategi pengembangan usahatani kopi lokal di Kabupaten Kepulauan Yapen yaitu mengoptimalkan lahan usahatani, menetapkan kawasan pengembangan usahatani kopi lokal yang terjangkau, melakukan seleksi klon-klon kopi lokal yang unggul dan menyediakan kebun koleksi,mengupayakan status lahan petani yang bersertifikat secara individu, mengusahakan kemitraan dan Meningkatkan sumberdaya manusia/petani kopi lokal di Kabupaten Kepulauan Yapen.

Kata kunci: Kopi lokal, Pengembangan, Strategi

\section{INTRODUCTION}

Indonesia Coffee plantation dominated by smallholders with total of area 1.26 million hectares or equal to $96 \%$ and the remaining $4 \%$ by large estate and private estates. The area of plantations managed by people about 2.12 million household farmers. Plantation development basically an effort to empower the people especially in the rural areas or villages to be the ability optimally manage their natural resources, conservation and sustainable and can be source of income for people, especially farmers in the rural or the village. In Indonesia, there are two variaties of coffee plants which developed that are Arabica and Robusta coffee. Currently, most of the cultivation of coffee dominated by robusta coffee $(90 \%)$ and the rest is arabica coffee $(30 \%)$. Both varieties of coffee plants have significant differences, in terms of taste and aroma (Direktorat Jenderal Bina Produksi Perkebunan,2014).

Robusta coffee is referred to as a local coffee because it can be grown traditionally. Local coffee quality is not the same also, because each region in the area, from Sabang to Merauke, has the characteristics of soil, climate, weather and different nutrients. That is why the local coffee of Indonesia can not be labeled as coffee Indonesia uniforms, but distinguished by name the area, where coffee is grown. Not only that, the quality of the coffee aroma and taste local also rely heavily on farming habits of farmers in each region in Indonesia is the averages wear intercropping system. Rahardjo, (2012). The area of local coffee 
in Kepulauan Yapen regency already recorded 173 hectares cultivated with area 215.111 hectares of potential land estates. While the amount of coffee production is 57 tons with an average productivity 432 $\mathrm{kg} /$ ha/year grown by 234 heads of family farm. Coffee plantation is situated in the mountains of central Yapen with altitude 1000-1500 meters above sea level with temperatures average per year reaching 18-28 degrees celsius. This fact illustrates that the development of local coffee farming system extension in Kepulauan Yapen regency is still great potential. BPS Kepulauan Yapen, (2014). The objects of this study are: (1) Identify and explain the internal factors (strengths and weaknesses) and external factors (opportunities and threats) local coffee farm in Kepulauan Yapen regency. (2) To formulate strategies for the development of local coffee farming system appropriate and applicable in Kepulauan Yapen regency.

\section{METHODS}

The basic method used in this research is descriptive analysis method. This research was conducted in Kepulauan Yapen Regency, Province of Papua. Determination of research areas is done intentionally (purposive) based on the consideration that the region is one of the local coffee production center. Sampling based on information required that are parts into 2 (two) groups. The first group, the competent local policy makers. The second group is local coffee farmers and tradercoffee beans. Data collection was done by interviewing, recording and questionnaire. The data used which primary data obtained directly from respondents and secondary data obtained from the institution related. The data analysis methods used are the Validity and Relialibility Test and SWOT Analysis.

\section{RESULTS AND DISCUSSION}

\section{Identification of Factors}

Identification carried out on various internal strategic environment factors that include strengths and weaknesses factors that are owned by local coffee farming system in kepulauan Yapen, and practiced identification of various external strategy environmental factors that includes opportunities and threats associated with the development of the local coffee farming system in kepulauan Yapen regency. The identification results through interviews and questionnaires were distributed to the respondents who have been determined. Obtained 44 items of questions consisting of 25 statement of internal strategic environmental factors, 12 (twelve) statement strenght factor and 13 (thirteen) statement weakness factors and 19 (Nineteen) statement external strategic environment factors consisting of 10 (ten) statement opportunity factor and 9 (nine) statement of threat factor. 
Table 1. Validity test Results for factors strengths, weaknesses, opportunities, and threats to determine the development strategy of Local Coffee Farming System in Kepulauan Yapen Regency

\begin{tabular}{|c|c|c|}
\hline Indicator & $\mathrm{r}$-count & Explain \\
\hline $\begin{array}{l}\text { A Strength } \\
\text { 1. Condition of according to farm which suited for agriculture of coffee }\end{array}$ & $0,782^{* *}$ & Valid \\
\hline 2 local Coffee productivity can be improved & $0,783^{* *}$ & Valid \\
\hline 3 Coffee Cultivation conducted hereditary by society & $0,900^{* *}$ & Valid \\
\hline 4 Existence of extension of local coffee farm per annum & $0,843^{* *}$ & Valid \\
\hline 5 The available of activity energy/farmer & $0,342^{*}$ & Valid \\
\hline 6 Condition of cultural social of society which still support. & $0,924^{* *}$ & Valid \\
\hline 7 The available source of local coffee seed & $0,865^{* *}$ & Valid \\
\hline 8. Policy of Local government supporting local coffee plantation & $0,852^{* *}$ & Valid \\
\hline $\begin{array}{ll}\text { B } & \text { Weakness } \\
1 & \text { Not yet is optimal exploiting of farming system }\end{array}$ & $0,563^{* *}$ & Valid \\
\hline 2 Most crop copy have is old & $0,595^{* *}$ & Valid \\
\hline 3 local coffee farming system location laid at widespread & $0,656^{* *}$ & Valid \\
\hline $\begin{array}{l}4 \text { The limited officer of extension agent of medium and field } \\
\text { infrastructure. }\end{array}$ & $0,752^{* *}$ & Valid \\
\hline 5 Not plant local coffee superior seed & $0,797^{* *}$ & Valid \\
\hline 6 The lower of local coffee cultivation technique & $0,364^{*}$ & Valid \\
\hline 7 Farmer land status of cooperative/group ownership. & $0,506^{* *}$ & Valid \\
\hline 8 The limited agriculture technology and information & $0,618^{* *}$ & Valid \\
\hline $\begin{array}{cl}\text { C } & \text { Opportunity } \\
1 & \text { Still wide available of land potential and climate supporting }\end{array}$ & $0,878^{* *}$ & Valid \\
\hline $\begin{array}{l}2 \text { Source of finance which close to activity of local coffee farming } \\
\text { system. }\end{array}$ & $0,939^{* *}$ & Valid \\
\hline 3 Demand of local coffee home affairs leave open widely & $0,905^{* *}$ & Valid \\
\hline 4 Investor enthusiasm is high for investment & $0,890^{* *}$ & Valid \\
\hline 5 Existence of regional autonomy & $0,929^{* *}$ & Valid \\
\hline D Threats & & \\
\hline 1 Difficult Price Fluctuation for predicting by farmer & $0,796^{* *}$ & Valid \\
\hline 2 Existence attack of pest and disease & $0,695^{* *}$ & Valid \\
\hline 3 expense Costly to release of land & $0,838^{* *}$ & Valid \\
\hline $\begin{array}{l}4 \text { Shifting pattern exploiting of coffee farming system to vegetable } \\
\text { farm. }\end{array}$ & $0,678^{* *}$ & Valid \\
\hline Weak position bargaining farmer to price sell dry coffee seed. & $0,761^{* *}$ & Valid \\
\hline
\end{tabular}

Source: Primary Data Analysis,2015

** significant at the 95\% confidence level ( $\alpha=0.05$ )

* significant at the $90 \%$ confidence level $(\alpha=0.1)$ 


\section{Validity Test}

According Ghozali (2006), the important thing to do in qualitative analysis using a questionnaire is to test the validity of a questionnaire based on strategic environmental factors, which will be formulated in the form of SWOT analysis. The purpose of the validity test is to determine the extent of the validity of a statement which used to measure the variables. The validity test each strategic environmental factors, both internal and external environmental factors on the development of local coffee farming system in kepulauan Yapen regency. Results Validity test for factors strengths, weaknesses, opportunities, and threats can be seen in Table 1 below.

Based on the table 1 above can be seen that the entire item statement has the highest $r$-count $>$ r-table so that all items of statement is valid and can be used for SWOT analysis for define local coffee farming system development strategy in Kepulauan Yapen regency. Validity test results obtained 26 valid statement or martyrdom that consisting of 16 statements for internal environmental factors, 8 (eight) statement of strength, 8 (eight) statement weakness and ten (10) statement for external environmental factors comprising of 5 (five) statement opportunity, 5 (five) statement threat.

\section{Reliability Test}

In addition to the validity test of each statement of research using quantitative data to test the accuracy of variables is also tests reliability. The test of measuring instrument in principle shows the extent of the measurement can give relative no different results measurements were taken back to the same object. Reliability test by used the criteria of alpha coefficient $(\alpha)$. Decision making criteria for reliability test is to compare the value of alpha coefficient count greater than or equal to value the variable of alpha comparison or measurement tool (Strengths, Weaknesses, Opportunities and Threats) and can be seen in Table 2 this below:

According to table 2 can be seen that the factors of strengths, weaknesses,

Table 2. Reliability test Key for Success in Development of Local Coffee Farming System in Kepulauan Yapen regency.

\begin{tabular}{llll}
\hline Variables & Count Alpha & Refer Alpha & Explain \\
\hline Strengths (S) & 0,60 & 0,942 & Reliable \\
Weaknesses (W) & 0,60 & 0,787 & Reliable \\
Opportunities (O) & 0,60 & 0,982 & Reliable \\
Threats (T) & 0,60 & 0,934 & Reliable \\
\hline
\end{tabular}


opportunities and threats has a value of $\alpha>0.70$ meaning that the variable or the measuring instrument used all of them are reliable and relatively very high reliability. Thus, four factors have a high accuracy to be used as a determining factor in the formulation of development strategies at the local coffee farming system in Kepulauan Yapen regency.

\section{SWOT Analysis}

SWOT analysis is to identify the various factors systematically to formulate development strategies at the local coffee farming system in kepulauan Yapen regency. This analysis is based on the logic that maximizes Strengths (S) and opportunities (O) but simultaneously can minimize weaknesses (W) and threats (T). Strategic decision making process is always associated with the development of the mission, goals, strategies and policies of local governments. Thus, strategic planning (strategic planner) should analyze the strategic factors of local government (Dinas Perkebunan) are the strengths, weaknesses, opportunities and threats in the current conditions.

\section{Internal and External Environmental} Analysis

Internal environmental analysis used to determine how much the strengths and weaknesses that are owned by local coffee farming system in Kepulauan Yapen regency includes variety of programs and activities that have been implemented by the Dinas Perkebunan Kepulauan Yapen regency. The purpose of the internal environment analysis to utilize the existing strengths and simultaneously overcome the weaknesses and getting development strategy local coffee farming system in the Kepulauan Yapen regency and right to be recommended for using of plan development strategies in the plantation sector Kepulauan Yapen regency. The external environment analysis expected to be identified opportunities and threats that come from the external environment in the development of the local coffee farming system in Kepulauan Yapen Regency.

\section{Determination Scoring}

The determination of scoring measured based on the observation through list of statements that have been prepared for each of strategic environmental factors. The multiplication of the weight by scoring of value will generate weighted values. From weighted value can be formulated into SWOT analysis diagram mapped in the horizontal axis (X) and the vertical axis (Y). The identification of internal and external environmental factors to determination of development strategy local coffee farming system in Kepulauan Yapen regency, and can be seen in Figure 1 Position of the development strategy as follows 


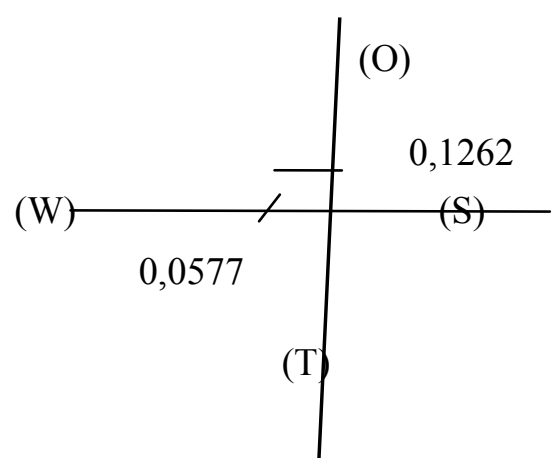

Figure 1 . Position of the development strategy

Source : Primary Data Analysis,2015

Figure 1 above showing the position of the development strategy of the local coffee farming system in Kepulauan Yapen regency in quadrant II (two). Position strategies shows that strategic development of local coffee farming system in Kepulauan Yapen regency really should be directed to remediation efforts towards weakness (W) held in the farming systems of local coffee in Kepulauan Yapen Regency, to be able to seize opportunities (O) there. Thus, strategic should be applied in the development of local coffee farming system is strategic Weakness - Opportunities (Strategic-WO). Given that Kepulauan Yapen regency in the development of the local coffee farming system is still in the stage of growing and

Table 3. Matriks IFAS-EFAS Strategic to Development of Local Coffee Farming System in Kepulauan Yapen Regency

\begin{tabular}{|c|c|}
\hline & Weaknesses - (W) \\
\hline $\begin{array}{l}\text { Environment } \\
\text { EFAS }\end{array}$ & $\begin{array}{l}\text { 1. Not yet is optimal exploiting of farming } \\
\text { system } \\
\text { 2. Most crop copy have is old } \\
\text { 3. local coffee farming system location laid at } \\
\text { widespread } \\
\text { 4. The limited officer of extension agent of } \\
\text { medium and field infrastructure. } \\
\text { 5. Not plant local coffee superior seed } \\
\text { 6. The lower of local coffee cultivation } \\
\text { technique } \\
\text { 7. Farmer land status of cooperative/group } \\
\text { ownership. } \\
\text { 8. The limited agriculture technology and } \\
\text { information }\end{array}$ \\
\hline Opportunities -(O) & Strategic $-($ WO $)$ \\
\hline $\begin{array}{l}\text { 1. Still wide available of land potential and } \\
\text { climate supporting } \\
\text { 2. Source of finance which close to activity of } \\
\text { local coffee farming system. } \\
\text { 3. Demand of local coffee home affairs leave } \\
\text { open widely } \\
\text { 4. Investor enthusiasm is high for investment } \\
\text { 5. Existence of regional autonomy }\end{array}$ & $\begin{array}{l}\text { 1. Land Optimizing } \\
\text { 2. Establish local coffee farming system in } \\
\text { development areas that are affordable } \\
\text { 3. Selection clones of local coffee and build a } \\
\text { garden collection } \\
\text { 4. Promote partnerships } \\
\text { 5. Promote the status of certified farmers land } \\
\text { individually } \\
\text { 6. Improving Human Resources/farmers }\end{array}$ \\
\hline
\end{tabular}

Source : Primary Data Analysis,2015 
developing the local government needs to implement a policy of aggressive growth (growth-oriented strategy)

\section{Alternative development strategies}

Alternative strategies that can be used in Kepulauan Yapen regency in efforts to develop local coffee farming system can be determined using SWOT matrix IFAS-EFAS. By combining the strategic factors that have been identified by internal environmental factors (strengthweaknesess) and external environmental factors (opportunity, threats), may be prepared several alternative strategic options (strategic choices) to be the direction on strategic combination of WO can be seen at IFAS-EFAS SWOT matrix as shown in Table 3 below.

Based on the SWOT matrix IFASEFAS above that the strategic position acquired is in quadrant II, the strategic priorities are focused on WeaknessOpportunities Strategy (W-O) that minimize weaknesses (W) to seize or take advantage of existing opportunities (O). Based on that of the matrix SWOT IFAS-EFAS above can be determined formulation core strategy which can be used as local coffee farming system development strategy in Kepulauan Yapen regency as follows:

1. Land Optimizing

Strategies to land optimize of local coffee farming system is in action cultivation techniques; replanting, rehabilitation of crops, intensification and expansion of the plant and to improve advisory services to farmers. Most of the local coffee farmers in kepulauan Yapen regency, are not familiar with the guidelines engineering crops that are good and right (Good agriculture Practices) are applied to the standard operating procedures of cultivation, it can be found on the farm are still traditional or turn generations and have not done intensively.

2. Establish local coffee farming system development areas that are affordable. Regional development of local coffee farming system is a center area local coffee development would established by local government or dinas perkebunan Kepulauan Yapen regency under the terms of growing coffee with accessibilities consider the carrying capacity, facilities and infrastructure such as adequate transportation. The main objective set local coffee farming system center area is to facilitate the evaluation and control of the Dinas perkebunan for programs and activities undertaken. If there are issues that can easily to be evaluated alternatives accomplish and recommend it as a program implemented in the next year.

3. Selection clones of local coffee and build a garden collections.

One program providing superior varieties is through the selection of local 
coffee clones to base that the farmer/ extension workers them can see that the superior seed quality can actually deliver what they want is a coffee plant local high yielding, resistant pests and disease. To experiment increase the yield it is necessary to provide a special land to build garden collection. The purpose built of the garden collection is with crossing clones superposing to produce new varieties of candidates then used as a plant that has high production levels. The reason the selection of local clones because many adoption of improved seed quality were distributed to the farmers is a fake seeds has cultivated so that the results unoptimal. Seed business is successful if it produces seeds, can optimally be adopted by farmers.

4. Promote partnerships

Efforts to develop local coffee farming system Kepulauan Yapen Regency faced with various constraints, among others: (1) the productivity of the plant below of normal potential; (2) variety of pests and diseases that are difficult to control by individual farmers; (3) low quality of dried coffee beans; (4) difficulty farmers get special funding for development local coffee. All this has made many efforts to improve the conditions such as the empowerment of farmers through field school integrated pest management (SL-PHT) and implementation of other technologies and the provision of seeds quality. Given the implementation is partially the result is not optimal. Therefore, these activities should be carried out simultaneously and comprehensively through an activity involving related parties to manage available resources through building a partnership with financial institutions, academia and research such as coffee and cocoa and coffee research center.

5. Promote the status of certified farmers land individually.

Farmers land is land managed by farmers and differenced over ownership rights to the land. The right to land can be divided into three things: property rights, lease rights and entitlement (sakap). Status of land ownership in the local coffee farmers Kepulauan Yapen regency is still in the status of common property or communal rights. While the role of land in farming as a production factor. Therefore, with the regional autonomy that gives the authority to regulate its own country, the Provincial Government made a special regional regulation Papua Province Number 23 Year 2008 on community land rights of indigenous and individual rights of citizens of indigenous people on the ground to give up some or all of the customary rights to citizens to be controlled by each resident as an individual right. 
6. Improve Human Resources/farmers

Efforts to improve human resources in particular local coffee farmers in Kepulauan Yapen regency is through the empowerment of farmers with training and assistance in order to improve the knowledge, skills and attitude changes gradually and continuously. The purpose of the training and technical assistance cultivation, post-harvest, institutional, financial management and business partnership is to create local coffee farmer independence in Kepulauan Yapen regency.

\section{CONCLUSION AND SUGESSTION}

\section{Conclusion}

Based on the analysis and evaluation of development strategies at the local coffee farming system in Kepulauan Yapen regency, it can be concluded some of the following;

1. Internal and external strategic Factors affecting determination of development strategy at the local coffee farming system in kepulauan Yapen regency covers factors; strength (s) are eight (8) statement, weakness (w) there are eight (8) statement, opportunities (o there are 5 (five) statements and threats (T) also there are five (5) statement that all items are valid statement and the high reliability means that all four factors have a very high accuracy to be made as a determining factor in the strategy to develop the local coffee farm in Kepulauan Yapen regency

2. SWOT analysis of the internal factors and external factors that are owned encountered in the development of the local coffee farming in the Kepulauan Yapen regency show that;

a) Total weighted strength value is 4.5514 less than the total value of the weighted of weakness 4.6091 which means that to minimize weaknesses, must be repaired as optimal so it can be turned into strength.

b) The total opportunities value is 4.6267 greater than the total value of the weighted threat is 4.5005 , which means that the opportunity to develop local coffee farming system in Kepulauan Yapen regency very well that the best use possible to anticipate threats.

3. Diagram of SWOT analysis shows that the strategic position in the development of local coffee farming system in quadrant II (two). Position stategis shows that strategic development of local coffee farming system in Kepulauan Yapen regency really should be directed to remediation efforts towards weakness (W) held in the 
farming systems of local coffee in Kepulauan Yapen Regency, to be able to seize opportunities (o) there. Thus, strategic should be applied in the development of the local coffee farming system is strategic Weakness - Opportunities (StrategicWO). Given that Kepulauan Yapen regency in the development of the local coffee farming system is still in the stage of growing and developing the government needs to implement a policy of aggressive growth (growthoriented strategy).

Core Strategy formulation that can serve as local coffee farming system in development strategy at Kepulauan Yapen regency based matrix SWOT IFAS-EFAS as follows:

1. Land Optimizing

2. Establish local coffee farming system in development areas that are affordable.

3. Selection clones of local coffee and build a garden collection

4. Promote partnerships

5. Promote the status of certified farmers land individually

6. Improving Human Resources/farmers

This strategy then can be translated in detail in the form of programs and activities that refers to the vision and mission of the Government of Kepulauan Yapen regency.

\section{Suggestion}

Refer to the results of the study, that the strategy can be set is Weaknesesopportunity to minimize weaknesses, suggested some of the following;

1. The farmers are expected to seek tenure are certified and are not tied to a group or collective rights/customary rights.

2. The farmers should be planting the superior seeds of local coffee coming from the garden collection well so can higher result in the production and productivity of coffee

3. The Farmers are expected to raise awareness of the importance of local coffee farming system as the main source of income and family income.

4. The Farmers should maintain good relations with the partners such as Dinas Perkebunan, Enterpreneur and fellow coffee farmers, so that could be established either

5. The farmers are expected to grow reinforcement and synergy between farmer groups in Kepulauan Yapen regency

6. The local government through the Dinas Perkebunan should establish intensive communication with relevant institutions such as the nearest financial institution (BRI, BPD Papua), Center for Research and Assessment of the area, Higher Education Institution in Indonesia and do research of coffee quality and affordable. 


\section{REFERENCES}

Badan Pusat Statistik Kabupaten Kepulauan Yapen. 2014. Kabupaten Kepulauan Yapen dalam Angka.Yapen : Badan Pusat Statistik Kabupaten Kepulauan Yapen

Dirjen Bina Produksi Perkebunan. 2014. Statistik Perkebunan, Kopi Robusta. Jakarta : Dirjen Bina Produksi Perkebunan.
Ghozali,I.2006.Aplikasi Analisis Multivariate dengan Program SPSS. Cetakan Keempat. Semarang : Universitas Diponegoro.

Rahardjo,P.2012. Panduan Budidaya dan Pengolahan Kopi Arabika dan Robusta. Cetakan Pertama. Jakarta : Penerbit. Penebar Swadaya. 